\title{
IMAJI BIBLIS DAN DOGMATIS TENTANG PERTOBATAN YANG MENGGEMBIRAKAN
}

\author{
Aloysius Wahyu Endro Suseno
}

\begin{abstract}
Abstrak:
Repentance is one of the most important theme in God's salvific plan for human being. Somehow nowadays, repentance seems unfavourable for many. People tend to look down on guilty feeling, avoiding any form of judgement or punishment, and to fall into misunderstandings of repentance as well as the sacrament of reconciliation. Repentance needs to be preached continuously, yet with a more positive approach. One way to do it is to use a joyful image of repentance, which indeed can be found in the Scripture and the Doctrine of Church. By finding those images, repentance will bring more joy, not only for the angels in heaven (cf. Luke 15:10), but for the people in the world, especially those who has good will to repent.
\end{abstract}

\section{Kata-kata Kunci:}

pertobatan, gambaran, gembira, dosa, rekonsiliasi.

\section{PENGANTAR}

Pertobatan menjadi tema penting dalam Kitab Suci. Pertobatan diserukan oleh para nabi sejak zaman Perjanjian Lama, Yohanes Pembaptis, dan berpuncak pada Yesus Kristus. ${ }^{1}$ Seruan pertobatan diteruskan oleh para rasul, ${ }^{2}$ lalu oleh Gereja. Pertobatan adalah jawaban konkret atas tawaran keselamatan Allah. Melalui Gereja, Yesus Kristus menyediakan sarana pertobatan terutama dalam Sakramen Rekonsiliasi. Gereja sendiri mengajarkan betapa pentingnya pertobatan bagi umat beriman.

Ortodoksi tentang pertobatan tidak selalu sejalan dengan ortopraksinya. Dalam hal Sakramen Rekonsiliasi, misalnya, Gereja mengajarkan bahwa pengakuan pribadi dan utuh serta absolusi merupakan cara biasa satu-satunya, dengannya orang beriman yang sadar akan dosa beratnya diperdamaikan kembali dengan Allah dan Gereja. ${ }^{3}$ Dalam praktiknya, pengakuan dosa pribadi sering dikeluhkan oleh banyak pastor dan umat sebagai sakramen yang tidak terlalu menggembirakan. ${ }^{4}$ Hal ini bisa disebabkan oleh pergeseran cara pandang umat terhadap pertobatan. Sebagai contoh, pada masa Konsili Trente saat Sakramen Rekonsiliasi ditetapkan, Gereja, imam, dan dogma dipandang sebagai jaminan keteraturan sosial dan moral yang memberi kepastian dan ketenangan batin, ${ }^{5}$ sehingga umat mudah menerima dan melaksanakan ajaran Gereja, termasuk tentang pertobatan. Di zaman Postmodern ini, kebenaran tidak lagi bisa dimonopoli oleh agama, ideologi, atau otoritas tertentu. ${ }^{6}$ Suatu ajaran, bahkan teks biblis sekalipun, dalam praktiknya kini bisa dikritik atas dasar rasionalitas, tidak lagi menjadi sesuatu yang pasti diterima begitu saja oleh semua umat Katolik di dunia. ${ }^{7}$

Ada beberapa gambaran pertobatan yang bisa diterima di masa lalu tapi kurang bisa diterima di masa kini. Contohnya adalah gambaran imam sebagai hakim. ${ }^{8}$ Gambaran 
tersebut tampak kurang sesuai dengan cara pandang manusia masa kini yang lebih menekankan kebebasan dan tanggung jawab pribadi. Jika imam digambarkan sebagai hakim, peniten akan digambarkan sebagai terdakwa, dan ruang pengakuan sebagai pengadilan. Ini akan memberi gambaran pertobatan sebagai penghakiman. Beberapa gambaran tradisional tentang pertobatan bisa kehilangan daya gunanya di kalangan umat zaman sekarang, sementara gambaran yang baru belum memiliki daya yang penuh. ${ }^{9}$ Sebagian orang zaman sekarang mungkin tidak bisa mengerti lagi formula dan ritus Kristen tradisional, sementara belum ada ritus dan formulasi baru yang sesuai dengan pengalaman manusia zaman sekarang tentang dirinya dan Tuhan. ${ }^{10}$ Ini bukan berarti bahwa gambaran pertobatan pada masa lalu itu keliru sehingga harus dikoreksi. Gambaran pertobatan perlu dilengkapi dengan interpretasi yang sesuai dengan ajaran Gereja dan pola pikir orang zaman sekarang.

Yang menjadi masalah bukanlah pertobatan itu sendiri, melainkan gambaran tentang pertobatan. Di satu sisi, manusia memang berdosa dan memerlukan pertobatan. Di sisi lain, pertobatan bisa memberikan kesan yang cenderung tidak menyenangkan, misalnya merasa bersalah, malu jika dosanya diketahui orang lain, dihakimi, takut dihukum, dan sebagainya. Yang diperlukan adalah gambaran tentang pertobatan yang menggembirakan, kontekstual, dan berdaya guna bagi umat. Tobat Kristiani adalah kegembiraan tobat, yaitu kegembiraan perjamuan Yesus dengan orang pendosa dan pemungut cukai, kegembiraan pesta karena bapa mendapatkan kembali anaknya yang hilang. ${ }^{11}$ Gambaran pertobatan yang kontekstual berarti berkaitan dengan konteks sosio-kultural dan keadaan psikologis umat, misalnya mencari gambaran yang tepat bagi orang-orang dengan kecenderungan budaya otonom yang tentu berbeda dari orang-orang dengan budaya kolektif. Pertobatan yang berdaya guna berarti terjadi perubahan sikap, mental, dan tindakan. ${ }^{12}$ Dengan begitu, pertobatan yang hakikatnya positif akan digambarkan secara positif pula.
Pertobatan perlu digambarkan sesuai dengan konteks zaman sekarang dan tetap berkesinambungan dengan pengajaran tradisi Gereja. ${ }^{13}$ Saya tertarik dengan tema sukacita yang diserukan Paus Fransiskus dalam Anjuran Apostolik Evangelii Gaudium sebagai cara baru berevangelisasi di zaman sekarang. Injil adalah Kabar Gembira. Karena itu seruan pertobatan semestinya juga menjadi seruan yang menggembirakan. Untuk itulah diperlukan gambarangambaran pertobatan yang menggembirakan pula, dan tetap sesuai dengan ajaran iman Gereja. Pertama-tama saya memberikan beberapa gambaran pertobatan dari Kitab Suci (biblis) selaku norma iman tertinggi. Saya juga memaparkan beberapa gambaran pertobatan dari dogma atau ajaran Gereja (dogmatis) yang terdapat di dalam dokumen Konsili Vatikan II.

\section{GAMBARAN-GAMBARAN PERTOBATAN}

Tema pertobatan selalu muncul dalam sejarah keselamatan. Dalam sejarah itu terdapat gambaran-gambaran pertobatan yang mencerminkan penghayatan umat akan pertobatan sesuai zaman masingmasing. Gambaran ini dinamis, berubahubah dari masa ke masa, karena dipengaruhi oleh penghayatan iman, situasi zaman, pola pikir manusia, paham teologis, dan sebagainya. ${ }^{14}$

Meski mengalami perubahan, ada kaitan di antara gambaran-gambaran pertobatan tersebut. Gambaran pertobatan di zaman sekarang tak bisa dilepaskan dari gambaran pertobatan dalam Perjanjian Lama, Perjanjian Baru, dan perjalanan sejarah Gereja. ${ }^{15}$ Gambaran pertobatan dalam Gereja saat ini mengacu terutama pada Kitab Suci sebagai landasan bagi teologi yang tanpa kekeliruan mengajarkan kebenaran dari Allah. ${ }^{16}$ Pengalaman iman dalam Kitab Suci selalu aktual dan punya arti bagi zaman sekarang. ${ }^{17}$ Selain dari Kitab Suci, gambaran pertobatan dalam dokumen-dokumen sejak Konsili Vatikan II juga penting untuk dilihat karena Gereja saat ini mengacu pada semangat pembaharuan Konsili Vatikan II. ${ }^{18}$ 


\section{Gambaran-gambaran Pertobatan dalam Perjanjian Lama}

Penghayatan umat Perjanjian Lama akan pertobatan bisa dilihat dari gambarangambaran pertobatan yang muncul pada zaman itu. Gambaran pertobatan dalam Perjanjian Lama berhubungan antara lain dengan pemahaman Israel akan Allah, perjanjian, simbol, dosa, dan malapetaka.

\section{Pertobatan Sebagai Ritus dan Perbuatan Sehari-hari}

Gereja mengajarkan bahwa kultus atau upacara keagamaan, termasuk sakramensakramen, tak bisa dipisahkan dengan sikap dan perbuatan sehari-hari. ${ }^{19}$ Keterkaitan ini tampak juga dalam Perjanjian Lama, termasuk dalam hal pertobatan. Pertobatan dalam Perjanjian Lama mengandung aspek yang berkaitan dengan kultus dan yang berkaitan dengan batin serta sikap hidup atau perbuatan. ${ }^{20}$

Aspek yang berkaitan dengan kultus.

Salah satu bentuk ungkapan pertobatan umat Israel adalah dengan melakukan ritus pertobatan. Israel mengenal hari pendamaian atau hari tobat yang disebut dengan Yom Kippur (lih. Im 16). Di hari itu, Israel didamaikan dengan Allah dan diampuni dosanya. $^{21}$ Dalam ritus tersebut, mereka bertobat dengan sepenuh hati, menyesali dosa, menyerahkan diri kepada perlindungan Allah, dan memperbarui niat untuk kembali kepada Allah. ${ }^{22}$

Ada beberapa tindakan yang melambangkan pertobatan, antara lain:

- Berpuasa dan menyampaikan korban bakaran (Im 16)

Pada Hari Pendamaian, Allah menyuruh umat Israel untuk berpuasa dan menyampaikan korban bakaran di Kemah Pertemuan sebagai penghapus dosa. Puasa merupakan ungkapan kerendahan hati (ayat 31). Dalam perkembangannya, puasa bisa bermakna kesedihan ${ }^{23}$, kepasrahan ${ }^{24}$, penyiksaan diri (Mzm 35:13), dan dikaitkan dengan amal kasih (Yes 58:6).

- Berkumpul untuk mengaku dosa (Ezr 9:1-15)
Pada zaman Ezra, banyak orang Israel yang melakukan kawin campur dengan penduduk di daerah pembuangan. Tindakan ini adalah dosa. Pada suatu hari orang-orang yang takut akan Allah berkumpul dan mendatangi Ezra. Setelah mengetahui bahwa banyak orang Israel telah berdosa dengan tidak setia kepada perintah Allah, Ezra berdoa, mengakui dosa orang-orang Israel yang tidak setia itu dan memohon ampun kepada Allah. Ezra berdoa mewakili umat Israel. Sebagai ungkapan tanggung jawab Ezra terhadap komunitasnya, ia tidak menyebut dosa itu sebagai dosa mereka, tapi dosa kami. Meski tak bersalah, ia menyatukan dirinya dalam kesalahan jemaat dan kebutuhan mereka akan pertobatan. Ezra memberi teladan solidaritas, ikut menanggung kesalahan komunitas, dan mau berdoa bagi orang lain. ${ }^{25}$

- Menaruh abu di atas kepala (Yer 6:26; Yun 3:6)

Abu dan debu merupakan simbol manusia yang kecil di hadapan Tuhan. ${ }^{26}$ Setelah diperkosa dan disuruh keluar oleh Amnon, Tamar menaruh abu di atas kepalanya sebagai bentuk ratapan (2Sam 13:19). Ketika dinubuatkan akan diserang oleh banyak bangsa, putri Sion disuruh berguling-guling dalam debu sebagai tanda perkabungan untuk diri sendiri (Yer 6:26).

Aspek yang berkaitan dengan batin dan sikap hidup atau perbuatan.

Pertobatan tidak hanya terkait dengan kultus, tapi juga menyangkut batin dan sikap hidup atau perbuatan. Pertobatan yang bersifat batiniah tampak misalnya dalam Kitab Yoel. Tawaran pertobatan perlu ditanggapi dengan kemauan yang penuh. Ini dinyatakan melalui firman Allah, "Berbaliklah kepada-Ku dengan segenap hatimu" (Yl 2:12). Ungkapan "koyakkanlah hatimu dan jangan pakaianmu" (Yl 2:13) menunjukkan pentingnya sikap batin yang mau bertobat. Upacara ritual keagamaan tidak dilarang, tapi jangan hanya menjadi upacara belaka. ${ }^{27}$ Pertobatan tidak cukup diungkapkan melalui upacara ritual dan sikap batin. Pertobatan juga perlu diwu- 
judkan melalui tindakan nyata yang berdimensi sosial, misalnya membuka belenggu-belenggu kelaliman, memerdekakan orang yang teraniaya, memecahmecah roti bagi orang yang lapar, memberi tumpangan kepada orang miskin yang tidak punya rumah, memberi pakaian kepada orang yang telanjang (Yes 58:6-7).

Aspek kultus menggambarkan pertobatan yang diungkapkan melalui upacara tobat. Pertobatan juga digambarkan sebagai perbuatan sehari-hari, baik yang bersifat batiniah maupun lahiriah, yang diungkapkan melalui perubahan sikap dan tindakan. ${ }^{28}$ Dalam tradisi para nabi, aspek yang terakhir lebih ditekankan. ${ }^{29}$ Pertobatan dalam upacara atau ritus yang berdimensi ilahi harus disertai dengan perubahan sikap batin dan tindakan yang berdimensi sosial. Kedua aspek ini tidak dapat dipisahkan.

Bagi sebagian umat, masa Prapaskah yang adalah masa istimewa untuk bertobat bagaikan rutinitas tahunan belaka. Mereka bisa jadi tidak tahu harus berbuat apa selama 40 hari masa pantang dan puasa itu di tengah rutinitas harian mereka. Sebagian umat beranggapan bahwa berbuat baik saja sudah cukup, sehingga tak perlu berpantang dan berpuasa. Laku tobat tampaknya dipisahkan dari perbuatan baik. Tema-tema APP yang muncul tiap tahun tak jarang hanya menjadi slogan yang cenderung diabaikan, terutama oleh kaum muda. Pertemuan APP cenderung ditanggapi secara pasif. Peserta pertemuan APP biasanya didominasi orang-orang tua dan jumlahnya sedikit, setidaknya bila dibandingkan dengan misa lingkungan atau doa lingkungan pada bulan Maria. ${ }^{30}$ Gambaran ini bisa merevisi kekeliruan pandangan tersebut, yang melihat pertobatan hanya dari satu aspek saja: hanya ritual atau hanya tindakan.

\section{Pertobatan Sebagai Tindakan Kembali Kepada Perjanjian}

Salah satu teologi Perjanjian Lama adalah teologi perjanjian. Teologi perjanjian ditemukan terutama dalam Kitab Ulangan. Allah (YHWH) dan Israel berjanji untuk setia satu sama lain, menciptakan relasi eksklusif. Allah menjamin bahwa Israel akan selalu berada dalam keadaan baik, dan Israel hidup dalam iman dan ketaatan kepada Allah. ${ }^{31}$ Dengan kata lain, Israel akan menjadi umat Allah dan YHWH akan menjadi Allah mereka (Kel 6:6; Im 26:12). Perjanjian antara Allah dan Israel diawali dengan perjanjian antara Allah dan Abraham. Perjanjian ini memuat janji berkat dari Allah dan ketaatan dari manusia. Dari satu pihak, Allah berjanji bahwa Abraham akan menjadi bapa sejumlah besar bangsa. Allah akan memberi keturunan yang banyak dan tanah bagi Abraham dan keturunannya. Dari pihak lain, Abraham harus memegang perjanjiannya dengan Allah turun-temurun (Kej 17:1-14).

Salah satu unsur dari formula perjanjian yang terdapat dalam Kitab Ulangan adalah "berkat dan kutuk" (Ul 27-28). ${ }^{32}$ Israel mendapat berkat jika taat kepada hukum Allah dan mendapat kutuk jika tidak taat kepada hukum Allah. ${ }^{33}$ Dalam Perjanjian Lama, dosa sering dihubungkan dengan bencana dan penderitaan. ${ }^{34}$ Allah akan menimpakan malapetaka kepada umat Israel jika mereka tidak mendengarkan suara-Nya. ${ }^{35}$ Agar bencana dan penderitaan itu bisa dikurangi atau dihindari, umat memohon ampun dari Tuhan. Sebagai contoh, Allah membatalkan malapetaka terhadap penduduk Niniwe karena mereka bertobat (Yun 3:10).

Peristiwa pembuangan ke Babel merupakan bencana yang berpengaruh besar terhadap pertobatan bangsa Israel. ${ }^{36}$ Pengalaman tersebut sungguh tidak membahagiakan, tapi sekaligus memberi kesadaran bagi Israel bahwa mereka telah menyimpang dari hukum Tuhan, mengkhianati perjanjian dengan YHWH. Pertobatan membawa umat Israel kembali kepada perjanjian mereka dengan Allah, kepada ketaatan kepada hukum-Nya sehingga kembali mendapat berkat, berada dalam keadaan damai dan sejahtera. Tindakan kembali kepada perjanjian ini menggambarkan kesadaran bahwa perjanjian itu bukanlah sesuatu yang membelenggu kebebasan umat Israel, melainkan sungguh membawa berkat dan membebaskan mereka dari dosa. Sebaliknya, tindakan menyimpang dari perjanjian akan menghasilkan dosa dan kutuk. 
Gambaran ini bisa digunakan di dalam konteks orang atau kelompok orang yang memiliki komitmen terhadap apa yang sudah dipilih dan diputuskan. Sebagai contoh, suami atau istri yang mengkhianati pasangannya bisa diajak bertobat dengan mengingat kembali janji perkawinan yang diikrarkan di hadapan Allah dan manusia dengan kehendak bebasnya sendiri dan tanpa paksaan.

\section{Pertobatan sebagai Perubahan Hidup}

Kata yang paling lazim digunakan dalam Perjanjian Lama untuk menyebut "tobat" adalah "shub" 37 , artinya: berubah haluan, datang lagi, kembali pada langkahlangkahnya, berputar arah meninggalkan yang jahat menuju Tuhan. ${ }^{38}$ Pertobatan digambarkan sebagai perubahan hidup, berbalik dari hidup lama yang tidak benar ke hidup baru yang benar. Tindakan ini mencakup dua hal:

\section{Berbalik kepada Allah.}

Meski berulang kali Israel berdosa, Allah tetap mengajak mereka bertobat, karena Ia pengasih dan penyayang, panjang sabar, dan berlimpah kasih setia (Yl 2:13). Jika Israel berbalik kepada Tuhan, maka Tuhan akan menyayangi dan memulihkan keadaan mereka (Ul 30:2-3), melepaskan mereka dari tangan orang Filistin (1Sam 7:3), mengampuni mereka, memberikan keadilan serta mendengarkan doa dan permohonan mereka (1Raj 8:46-50), mengumpulkan dan membawa mereka kembali ke tempat yang telah dipilih-Nya (Neh 1:9).

Berbalik kepada Allah merupakan gambaran pertobatan dalam konteks relasi dengan Allah, berkaitan dengan disposisi batin terhadap Allah, dilakukan dengan segenap hati dan segenap jiwa ${ }^{39}$, dan dengan iman. Umat Israel bertobat sebab mereka percaya bahwa Allah mengampuni orang yang hatinya remuk redam (Mzm 51:9). Berbalik kepada Allah juga berkaitan dengan aspek kultus, yaitu meninggalkan berhala dan kembali beribadah kepada Allah. ${ }^{40}$

Meskipun sama-sama berhubungan dengan Allah, gambaran berbalik kepada Allah agak berbeda dengan berbalik kepada perjanjian. Berbalik kepada perjanjian berarti kembali mendapat berkat. Gambaran ini lebih menekankan keinginan untuk memperoleh berkat dan menghindari kutuk. Berbalik kepada Allah lebih menekankan keinginan untuk berelasi intim dengan Allah secara personal, baik melalui peribadatan maupun sikap batin.

\section{Berbalik dari tingkah laku yang jahat.}

Para nabi selalu menyerukan pertobatan kepada umat Israel dan agar mereka berbalik dari perbuatan dan tingkah laku yang jahat. ${ }^{41}$ Berbalik dari tingkah laku yang jahat merupakan gambaran pertobatan dalam konteks relasi manusia dengan sesamanya. Pertobatan diwujudkan dalam perubahan tingkah laku, yaitu dari yang jahat menjadi baik. Contoh perbuatan baik yang terdapat dalam Kitab Nabi-nabi antara lain: mengusahakan keadilan, mengendalikan orang kejam, membela hak anak yatim dan janda (Yes 1:16-17), membuka belenggu kelaliman, memerdekakan orang yang teraniaya, memecah-mecah roti bagi orang yang lapar, memberi tumpangan kepada orang miskin yang tidak punya rumah, memberi pakaian kepada orang yang telanjang (Yes 58:6-7), tidak menindas orang asing, tidak menumpahkan darah orang tak bersalah (Yer 7:6), tidak berbuat curang (Yeh 33:14-15), membenci kejahatan dan mencintai yang baik (Am 5:15), setia dan rendah hati (Mi 6:8), dan sebagainya. ${ }^{42}$

Berbalik kepada Allah tak dapat dipisahkan dari berbalik dari tingkah laku yang jahat. Berbalik kepada Allah merupakan perubahan sikap batin yang disertai dengan perubahan tingkah laku sehari-hari. Disposisi batin menggerakkan terjadinya perubahan tingkah laku ${ }^{43}$, dan perubahan tingkah laku merupakan wujud nyata perubahan batin. Gambaran ini menonjolkan aspek relasional manusia, yaitu dengan Allah (vertikal) dan sesama (horizontal). Dalam konteks manusia yang sangat menyadari diri sebagai makhluk yang berelasi dengan Allah dan sesama, gambaran ini tentu akan sangat mengena. Contohnya adalah dengan kultur Jawa yang mengenal istilah "sing eling lan waspada" (ingatlah dan berwaspadalah). Eling bisa dikaitkan dengan relasi manusia dengan Allah, yaitu selalu ingat bahwa manusia berasal dari 
Allah. Waspada bisa dikaitkan dengan relasi manusia dengan sesama, yaitu ajakan untuk selalu bersikap mawas diri. ${ }^{44}$

\section{Pertobatan sebagai Pengakuan Dosa}

Mengaku dosa dan mohon pengampunan adalah reaksi yang tepat ketika berbuat dosa, terutama dosa besar. ${ }^{45}$ Pengakuan dosa didorong terutama oleh kesadaran akan dosa, sikap rendah hati di hadapan Tuhan, dan niat untuk berdamai dengan Allah. ${ }^{46}$ Dilihat dari subjek yang mengaku dosa, pengakuan dosa ini bisa dilakukan secara personal (pribadi) maupun komunal (bersama-sama).

\section{Pengakuan dosa secara personal.}

Perintah untuk mengaku dosa bila bersalah sudah ada sejak Kitab Taurat. Orang yang berdosa terhadap sesamanya harus mengakui dosanya dan membayar tebusan (Im 5:5-6; Bil 5:6-7). Salah satu contoh kisah yang menunjukkan pengakuan dosa secara personal adalah pertobatan Daud. Daud berdosa terhadap Uria karena menghampiri Batsyeba dan mengirim Uria, suami Batsyeba, ke medan perang hingga gugur. Daud bertobat setelah diperingatkan oleh Nabi Natan (2Sam 12:1-14; Mzm 51:5).

Pengakuan dosa secara komunal.

Pengakuan dosa juga bisa dilakukan secara komunal. Allah akan mengingat perjanjian-Nya dengan Abraham, Ishak, dan Yakub bila umat Israel mengakui kesalahan mereka dan nenek-moyang mereka (Im 26:40-42). Ada beberapa contoh pengakuan dosa secara komunal yang dilakukan oleh Israel, antara lain:

- Israel mengaku kepada Tuhan bahwa mereka berbuat dosa terhadap-Nya, meninggalkan Allah dan beribadah kepada Baal (Hak 10:10; 1Sam 7:6). Mereka secara bersama-sama mengakui dosa yang mereka buat sendiri.

- Israel memisahkan diri dari semua orang asing untuk mengakui dosa, yaitu dosa mereka dan nenek moyang mereka, dan mendengarkan Taurat (Neh 9:2).

- Nehemia berdoa, mengakui dosanya sendiri, dosa keluarganya, dan dosa Israel (Neh 1:5-6). Bangsa Israel tidak mengaku dosa secara bersama-sama, melainkan melalui perwakilan. Nehemia bertindak selaku wakil Israel untuk mengaku dosa dan memohon ampun kepada Tuhan. Tindakan serupa juga dilakukan oleh Daniel ketika ia berdoa, mengakui dosanya dan dosa bangsa Israel, lalu memohon ampun kepada Tuhan (Dan 9:20-21).

Gambaran pertobatan sebagai pengakuan dosa lebih menekankan kerendahan hati ketimbang sekadar memenuhi kewajiban untuk melakukan ritus pertobatan. Upacara tobat dimotivasi pertama-tama oleh sikap tobat yang benar. ${ }^{47}$ Melalui pengakuan dosa, dengan rendah hati umat Israel menyatakan diri sebagai orang berdosa sehingga merusak relasi dengan Allah dan sesama. Mereka sadar bahwa mereka patut mendapat hukuman karena dosa yang dilakukan. Agar bisa berdamai dengan Allah dan sesama, serta terhindar dari hukuman, mereka mengaku dosa dan memohon ampun kepada Tuhan. Dalam masyarakat guilt culture yang menghayati kedosaan dalam bingkai budaya rasa bersalah, orang merasa berdosa karena sadar telah melakukan kesalahan meskipun belum ada seorang pun yang mengetahuinya. ${ }^{48}$ Dalam konteks ini, gambaran pertobatan sebagai pengakuan dosa tentu tidak akan membuat orang merasa seperti pengecut, melainkan justru menampilkan diri sebagai orang yang berani mengakui kesalahan karena merasa bersalah.

\section{Pertobatan Sebagai Kemenangan Atas Ketakutan}

Salah satu alasan yang mendorong pertobatan Israel adalah keyakinan bahwa Allah akan mengampuni orang yang bertobat. Situasi akan berbeda jika seseorang tidak yakin atau bahkan takut bahwa dosanya tidak akan diampuni. Ini dialami oleh Yakub ketika ia berkonflik dengan Esau, kakaknya. ${ }^{49}$

Yakub mendapat berkat dari Ishak, ayahnya, yang seharusnya diberikan kepada Esau selaku putra sulung (Kej 25-33). Yakub lari karena Esau menaruh dendam, bahkan hendak membunuhnya (27:41-45). Setelah bertahun-tahun, Esau mendatangi Yakub. Yakub takut dan ingin menenangkan hati 
Esau dengan cara mengirim persembahan kepada kakaknya itu sebelum bertemu dengannya (32:20). Pada malam sebelum bertemu Esau, Yakub bergulat dengan seorang pria hingga fajar (32:24-32). Itu adalah pergumulan Yakub melawan Allah dan manusia. Yakub menang dan mendapat berkat. Pertemuannya dengan Esau menjadi pertemuan yang menyatukan dan mendamaikan. ${ }^{50}$ Yakub yang awalnya takut bertemu Esau kini malah melihat wajah Esau seperti melihat wajah Allah (33:10).

Kisah ini memperlihatkan gambaran pertobatan sebagai kemenangan atas ketakutan. Yakub mengalahkan ketakutannya dengan cara menemui orang yang membuatnya takut. Demikian pula Esau. Ia mengalahkan rasa dendamnya dan menerima Yakub tanpa takut dicurangi lagi. ${ }^{51}$ Proses rekonsiliasi ini terjadi berkat campur tangan Allah saat menguatkan Yakub untuk bergumul dengan-Nya dan diri sendiri. Bersama Allah, ketakutan dan permusuhan di antara Yakub dan Esau berganti menjadi persatuan kembali dua saudara.

Peran Allah dalam diri Yakub mirip dengan yang digambarkan dalam Mazmur 23, "Sekalipun aku berjalan dalam lembah kekelaman, aku tidak takut bahaya, sebab Engkau besertaku." Yakub memiliki kekhawatiran akan masa depan, yaitu Esau yang datang untuk membalas dendam. Pergumulannya dengan Allah membuat Yakub berani menghadapi ketakutannya sendiri. Yakub tidak tahu apa yang akan terjadi, tapi ia tahu bahwa Allah akan memimpin dan menyertainya. Yakub hanya perlu mengikuti-Nya. ${ }^{52}$

Bebas dari rasa takut merupakan gambaran yang jauh lebih menggembirakan daripada gambaran tentang pengadilan, penghakiman, dan hukuman. Dengan gambaran ini, proses rekonsiliasi justru membuat pihak-pihak yang sebelumnya berkonflik kini memiliki relasi yang lebih intim.

\section{Pertobatan sebagai Anugerah Allah}

Pertobatan tidak hanya digambarkan sebagai usaha atau tindakan manusia belaka. Pertobatan juga digambarkan sebagai anugerah Allah. Yang bertobat memang manusia, tapi Allah memungkinkan manu- sia untuk bertobat. Ketika manusia berdosa, Allah tidak menutup pintu perdamaian. Allah memberi kesempatan sehingga pertobatan sangat mungkin dilakukan.

Berulang kali Israel melanggar janji setia kepada Allah sehingga mereka disebut sebagai bangsa yang tegar tengkuk (Kel 32:9), keras kepala, dan tegar hati (Yeh 2:4). Meski begitu, Allah tetap membuka pintu pertobatan bagi mereka. Allah tidak hanya menunggu, tapi menggerakkan mereka untuk bertobat. Allah memberikan hati yang baru dan taat, roh yang baru di dalam batin, serta menjauhkan hati yang keras (Yeh 36:26). ${ }^{53}$ Dalam peristiwa pembuangan bangsa Israel, Allah mengingat kebaikan orang-orang Yehuda yang turut dibawa ke pembuangan. Allah akan memberikan kepada mereka suatu hati untuk mengenal bahwa Allah adalah Tuhan. Mereka akan bertobat kepada Allah dan menjadi umatNya (Yer 24:7). Dalam pertobatannya setelah berdosa terhadap Uria, Daud memohon kepada Allah agar hatinya ditahirkan dan batinnya diperbarui dengan roh yang teguh (Mzm 51:12).

Pertobatan bukanlah semata-mata prestasi manusia. Pertobatan bukan hanya terjadi karena kesadaran, inisiatif, kemauan, dan keberanian manusia. Allah memegang peranan besar dalam pertobatan manusia. Allah menggerakkan hati manusia untuk bertobat. Allah membuka pintu pengampunan bagi manusia yang bertobat. Anugerah Allah dalam pertobatan tidak menghilangkan peran manusia. Gambaran ini tidak berarti bahwa satu-satunya yang berperan adalah Allah sehingga manusia hanya menunggu pengampunan dan tidak perlu mengusahakan pertobatan. Gambaran ini justru menampakkan aspek kerja sama antara Allah dan manusia dalam pertobatan.

Melihat pertobatan sebagai anugerah atau pemberian Allah terasa lebih positif jika dibandingkan misalnya dengan gambaran pertobatan sebagai tuntutan Allah. Analoginya adalah ketika seseorang yang bersalah diminta untuk minta maaf kepada orang yang telah ia sakiti. Mungkin ada rasa terpaksa, merasa diposisikan sebagai pelaku kejahatan, dsb. Nuansanya tentu berbeda ketika orang yang dirugikan tersebut tetap 
membuka diri dan tidak menutup pintu terhadap orang yang bersalah. Di sini ada kebebasan dari orang yang bersalah untuk memanfaatkan pintu maaf yang senantiasa tersedia baginya.

\section{Gambaran-gambaran Pertobatan dalam Perjanjian Baru}

Dalam Perjanjian Baru, muncul beberapa gambaran pertobatan yang tidak lagi didasarkan semata-mata pada kultus, legalitas, dan ancaman. Perjanjian Baru lebih menggambarkan pertobatan sebagai kabar sukacita, warta keselamatan dari Allah, serta pengalaman dikasihi Allah melalui perjumpaan dengan Yesus. Pertobatan membuat orang makin mengenal diri sendiri, sesama, dan Allah.

\section{Pertobatan sebagai Warta Gembira}

Dalam Perjanjian Baru, seruan pertobatan tidak selalu disertai dengan ancaman hukuman bagi yang tidak melakukannya. Injil Matius mengisahkan bahwa Yesus mengawali karya-Nya dengan berseru, "Bertobatlah, sebab Kerajaan Surga ${ }^{54}$ sudah dekat!" (Mat 4:17). Seruan Yesus ini paralel dengan kalimat pertama Yesus dalam Injil Markus, "Waktunya telah genap; Kerajaan Allah sudah dekat. Bertobatlah dan percayalah kepada Injil!" (Mrk 1:15).

Seruan tersebut bersifat indikatif dan imperatif5. "Waktunya telah genap; Kerajaan Allah sudah dekat" merupakan kalimat indikatif. "Telah genap" menyatakan bahwa Kerajaan yang sudah lama dinantikan kini sudah datang. "Sudah dekat" menyatakan bahwa Kerajaan Allah masuk ke dalam sejarah dalam diri Yesus untuk membawa keselamatan. Hal ini paralel dengan kisah Yesus yang mewartakan kabar baik penggenapan nubuat Yesaya tentang tahun rahmat Tuhan (Luk 4:14-21). ${ }^{56}$ Kerajaan Allah telah hadir dalam diri Yesus, dan akan hadir lagi saat kedatangan Yesus yang kedua. ${ }^{57}$ Jawaban yang tepat terhadap kedatangan Kerajaan adalah bertobat dan menerima kabar baik tentang keselamatan itu $^{58}$ Ini dinyatakan dalam kalimat imperatif, "Bertobatlah dan percayalah kepada Injil!"
Kerajaan Allah digambarkan dengan sukacita. Kerajaan Allah ibarat harta terpendam sehingga orang yang menemukannya bersukacita dan rela menjual seluruh miliknya demi harta itu (Mat 13:44). Kerajaan Allah digambarkan sebagai pesta perkawinan (Mat 22:1-14). ${ }^{59}$ Orang yang masuk Kerajaan Surga akan duduk makan bersama-sama dengan Abraham, Ishak, dan Yakub (Mat 8:11). Harta dan perjamuan adalah gambaran yang menyenangkan. Sebaliknya, gambaran yang menakutkan seperti dapur api, terdapat ratap dan kertak gigi muncul apabila orang tidak masuk ke dalam Kerajaan itu (Mat 13:42).

Warta tentang Kerajaan Allah tak bisa dipisahkan dari pertobatan. Kabar gembira itu ditanggapi dengan pertobatan. Motif pertobatan bukanlah ketakutan akan pengadilan Allah, tapi rasa syukur dan sukacita atas kebaikan Allah. ${ }^{60}$ Pertobatan didasari oleh sukacita dan sekaligus membawa sukacita. Pertobatan satu orang saja akan membawa sukacita di surga (Luk 15:7.10).

\section{Pertobatan Sebagai Pengalaman Berjumpa dengan Yesus}

Yesus datang untuk memanggil orang berdosa supaya mereka bertobat (Luk 5:32). Kisah Zakheus (Luk 19:1-10) merupakan contoh pelaksanaan misi Yesus ini. Zakheus adalah pemungut cukai yang boleh memungut sebanyak mungkin uang. Ia mendapat keuntungan dari selisih antara uang yang diterima dan yang harus disetorkan kepada pemerintah. Orang dengan profesi ini dianggap berdosa dan dijauhi oleh masyarakat Yahudi. Keinginan Yesus untuk menumpang di rumah Zakheus mengetuk hati Zakheus untuk bertobat. Tidak disebutkan bahwa Yesus mengancam atau menunjukkan kesalahan Zakheus. Perjumpaan dengan Yesus itulah yang membuat Zakheus bertobat. Pertobatan itu ditunjukkan dengan keputusan Zakheus untuk memberikan setengah hartanya kepada orang miskin dan mengganti empat kali lipat kerugian orang yang pernah diperasnya. ${ }^{61}$

Contoh lain adalah perempuan yang kedapatan berzinah (Yoh 7:53-8:11). Menurut Hukum Taurat, perempuan itu harus dirajam. Jika Yesus membolehkan 
hukuman itu, Ia tidak akan dikenal sebagai pengampun. Jika Yesus membebaskannya dari hukuman, Ia melanggar Hukum Taurat. Yesus lalu menantang orang-orang yang hadir untuk melihat kedosaan diri sebelum menghakimi orang lain karena mereka hanya melihat hukum dari kata-katanya, bukan intensinya untuk keselamatan manusia. Setelah mereka semua pergi tanpa ada yang menghukum perempuan itu, Yesus berkata kepadanya bahwa Ia pun tidak akan menghukumnya. Yesus malah memintanya untuk pergi dan bertobat. ${ }^{62}$

Zakheus dan perempuan tersebut bertobat setelah mengalami perjumpaan dengan Yesus yang menyapa, mengunjungi, dan tidak menghakimi. Tindakan Yesus tidak didasarkan semata-mata pada hukum, tapi pada kasih Allah yang menawarkan pengampunan. Seperti Zakheus dan perempuan tersebut, tanggapan yang tepat atas pengalaman dikasihi Allah itu adalah pertobatan. ${ }^{63}$

Kaum Farisi dan ahli-ahli Taurat mengucilkan orang berdosa, sehingga mereka bersungut-sungut ketika melihat Yesus makan bersama para pendosa (Luk 15:2). Orang yang berdosa digambarkan sebagai orang yang tidak memiliki akses untuk berjumpa dengan Yesus. Gambaran pertobatan sebagai perjumpaan dengan Yesus ini justru kebalikannya. Para pendosa yang bertobat justru patut bergembira karena mengalami perjumpaan dengan Yesus.

\section{Pertobatan Sebagai Intimasi}

Salah satu contoh orang yang bertobat secara luar biasa adalah Paulus. Saulus adalah penganiaya para pengikut Kristus yang setelah bertobat menjadi Paulus, pewarta Kristus. Pertobatan membawanya ke relasi mendalam dengan diri sendiri, sesama, dan Allah. ${ }^{64}$

\section{Intimasi dengan diri sendiri}

Paulus adalah orang Yahudi yang berkewarganegaraan Romawi. Ia taat kepada Hukum Taurat (Flp 3:4-6) dan memiliki kuasa untuk menangkap para pengikut Kristus (Kis 9:1-2). Setelah bertobat, Paulus sadar bahwa selama ini ia melakukan kejahatan. Sebenarnya ia menyukai hukum
Allah di dalam batinnya. Kejahatan itu terjadi bukan karena kehendaknya, tapi karena dosa yang ada dalam dirinya. Ia bertindak berdasarkan kehendak dosa, bukan atas kehendak dirinya sendiri (Rm 7:15-23) ${ }^{65}$ Paulus menampilkan figur yang bukan dirinya sendiri. Pertobatan membuatnya akrab dengan diri sendiri, tampil sebagai pribadi autentik, mengenal jati diri dan kehendaknya sendiri.

\section{Intimasi dengan sesama}

Sebelum bertobat, Paulus adalah ancaman bagi para pengikut Kristus. Setelah Paulus bertobat, para murid tidak secara otomatis mau menerimanya. Ketika Paulus mencoba bergabung, mereka takut kepadanya karena tidak percaya bahwa ia juga seorang murid (Kis 9:26). Paulus merasa sendirian. Dalam situasi ini, dan juga kemudian dalam perjalanan kerasulannya, Paulus diteguhkan dan didukung oleh banyak orang. Paulus yang tadinya adalah musuh berubah menjadi bagian dari Rasul Kristus. Paulus pun memiliki hubungan yang akrab dengan jemaat. Dalam surat-suratnya kepada seseorang atau jemaat, Paulus hampir selalu menuliskan ucapan syukur atas mereka. ${ }^{66}$

\section{Intimasi dengan Allah}

Intimasi dengan diri sendiri dan sesama yang dialami Paulus tidak ada artinya tanpa intimasi dengan Allah. Pengalaman akan Kristus memberi makna kepada proses autentisitas diri (intimasi dengan diri sendiri) dan persahabatannya (intimasi dengan sesama). Pertobatan Paulus bukan melulu proses manusiawi belaka, melainkan juga proses rahmat, proses pengenalan akan Allah. Kebutaan yang dialami Paulus dalam perjalanannya ke Damsyik memperlihatkan kebutaan pribadinya. Setelah disembuhkan, Paulus mampu mendengarkan suara Tuhan dan memahami kehendak-Nya. Pengenalan yang sejati akan Tuhan ini mendorong Paulus menjadi saksi Kristus. Ia pun memaknai hidupnya sebagai Kristus yang hidup dalam dirinya (Gal 2:20) ${ }^{67}$

Kisah pertobatan Paulus memberi gambaran pertobatan sebagai intimasi. Pertobatan Paulus tidak terjadi dalam sekejap, tetapi membutuhkan proses panjang. 
Pertobatan adalah proses mengenal diri sendiri, sesama, dan terutama Allah yang telah memanggilnya kepada pertobatan. Seperti Paulus, diperlukan proses panjang untuk bisa sampai pada intimasi tersebut. Situasi intim, akrab, "at home", akan memunculkan perasaan damai, gembira, dan bahagia. Proses intimasi ini bersifat kodrati dan selaras dengan tujuan eksistensial manusia, yaitu mencari kebahagiaan. Sebaliknya, situasi tidak "at home" akan memunculkan rasa cemas, gelisah, stres, dan tidak bahagia. ${ }^{68}$

\section{Pertobatan Sebagai Pembentukan Identitas}

Salah satu gambaran pertobatan dalam Perjanjian Lama adalah kembalinya umat Israel kepada identitasnya sebagai umat Allah, umat perjanjian. Gambaran ini mengalami perkembangan dalam Perjanjian Baru. Ini sejalan dengan berkembangnya makna identitas jemaat Perjanjian Baru, di antaranya sebagai anak Allah, murid Kristus, dan komunitas umat beriman.

\section{Sebagai anak Allah}

Dalam perumpamaan tentang anak yang hilang (Luk 15:11-32), si bungsu bertobat setelah menyadari keadaannya yang hampir mati kelaparan. Keadaan itu jauh berbeda dengan keadaan di rumahnya sendiri yang berlimpah-limpah makanannya (ayat 17). Identitasnya adalah anak bapa, tinggal di rumah bapa, memiliki semua yang dimiliki bapanya (bdk. ayat 31). Dosa yang telah dibuatnya membuat anak bungsu tersebut merasa tak layak lagi menyandang identitas sebagai anak bapa (ayat 18-19). Kesadaran inilah yang membawanya bertobat dan pulang kepada bapanya, dan mendapatkan identitasnya kembali sebagai anak bapa. ${ }^{69}$

\section{Sebagai murid Kristus}

Petrus adalah murid Yesus yang istimewa. Yesus menjadikan Petrus fondasi bagi jemaat-Nya dan memberinya kuci Kerajaan Surga (Mat 16:18-19). Meski demikian, Petrus tiga kali menyangkal Yesus (Mat 26:69-75; Mrk 14:66-72; Luk 22:5462; Yoh 18:15-27). Petrus lalu menyesal. Iman dan identitasnya sebagai murid Yesus yang sempat terguncang dalam peristiwa salib kembali pulih dengan peristiwa kebangkitan Yesus. Tiga kali pernyataan Petrus bahwa ia tidak mengenal Yesus dipulihkan oleh tiga kali pernyataan bahwa ia mengasihi Yesus (Yoh 21:15-19). Penyangkalan berubah menjadi pengakuan kasih kepada Yesus. Ketika Perjamuan Terakhir, Petrus membantah nubuat Yesus tentang penyangkalannya (Mat 26:35; Mrk 14:31). Petrus tidak percaya bahwa Yesus lebih tahu tentang dirinya ketimbang ia sendiri. Kini ia mengaku bahwa Yesus mengetahui hatinya. Ia kembali kepada identitasnya sebagai murid Kristus. Karena itu ia menerima tugas yang diberikan Kristus untuk menggembalakan domba-domba-Nya. ${ }^{70}$

\section{Sebagai komunitas umat beriman}

Pada peristiwa Pentakosta, Petrus memberikan kesaksian iman akan Paskah Kristus. Sesuai ajakan Petrus, orang-orang yang menerima perkataan itu lalu bertobat (Kis 2:37-38). Orang-orang ini membentuk suatu persekutuan atas dasar pengalaman iman akan Kristus. ${ }^{71}$ Pertobatan membuat mereka tergabung dalam satu identitas, yaitu komunitas umat beriman.

Pertobatan membentuk atau mengembalikan identitas seseorang sebagai anak Allah, murid Kristus, dan komunitas umat beriman. Bagi orang yang belum mengenal Allah, pertobatan memberikan identitas tersebut. Identitas itu bisa ternoda bahkan hilang oleh dosa. Bagi orang yang menyimpang dari identitasnya, pertobatan membawa seseorang kembali kepada identitasnya itu. Proses pengenalan dan pembentukan identitas diri merupakan sesuatu yang akan selalu relevan bagi hidup manusia, karena manusia akan selalu bertanya tentang identitas dirinya sendiri. ${ }^{72}$

Pembentukan identitas ini terjadi melalui relasi dengan yang lain. Manusia pada dasarnya bukanlah pertama-tama suatu individu yang sudah jadi lantas berelasi, melainkan relasi-relasilah yang menjadikan individu. ${ }^{73}$ Karena itu pertobatan sebagai pembentukan identitas tak lepas dari relasi manusia dengan yang lain. Anak bungsu dalam perumpamaan tentang anak yang hilang meninggalkan kehidupannya yang kelam dan kembali menjalin relasi dengan bapanya. Petrus menggembalakan domba- 
domba yang dipercayakan Yesus kepadanya dan memuliakan Allah dengan kematiannya (bdk. Yoh 21:18-19) setelah terjadi interaksi dengan Yesus (Yoh 21:15-17). Jemaat perdana bertekun dalam pengajaran rasulrasul dan dalam persekutuan, selalu berkumpul untuk memecahkan roti dan berdoa. Segala kepunyaan mereka adalah kepunyaan bersama, selalu ada dari mereka yang menjual harta miliknya, lalu membagibagikannya kepada semua orang sesuai dengan keperluan masing-masing, dengan bertekun dan dengan sehati berkumpul tiaptiap hari dalam Bait Allah. Mereka memecahkan roti di rumah masing-masing secara bergilir dan makan bersama-sama dengan gembira dan dengan tulus hati sambil memuji Allah (Kis 2:41-47). Jemaat perdana membentuk identitasnya karena ada relasi dengan para rasul dan dengan sesama jemaat.

\section{Pertobatan Sebagai Kebutuhan akan Allah}

Unsur kerendahan hati dalam pertobatan sudah muncul sejak Perjanjian Lama. Kerendahan hati ini mencakup kesadaran, pengakuan, dan penyesalan atas dosa yang dilakukan. Titik beratnya adalah diri sendiri sebagai orang berdosa di hadapan Tuhan, bukan membandingkan diri sendiri dengan orang lain.

Dalam perumpamaan tentang orang Farisi dan pemungut cukai (Luk 18:9-14), Yesus menegaskan bahwa orang yang berdosa, hina dina, dianggap sebagai sampah masyarakat, dapat memperoleh keselamatan dengan bertobat. Dalam kisah ini, pemungut cukai digambarkan sebagai pendosa yang merasa rendah di hadapan Allah sehingga tidak berani menengadah ke langit (ayat 13). Ia membutuhkan Allah yang ia yakini berkenan mengampuni dosanya. Orang tersebut menyerahkan diri sepenuhnya ke dalam belas kasihan Allah. Sikap ini berbeda dengan orang Farisi yang sudah merasa benar, taat pada hukum, bahkan melakukan lebih dari yang dituntut dari Hukum Taurat (ayat 12). Ia menganggap dirinya jauh lebih terhormat dibanding perampok, orang lalim, pezinah, dan pemungut cukai (ayat 11). Justru dengan begitu ia menyombongkan diri di hadapan Allah, tidak merasa membutuhkan Allah, dan tidak butuh pertobatan. ${ }^{74}$

Seperti orang Farisi dalam kisah tersebut, orang yang tidak membutuhkan Allah juga tidak akan membutuhkan pertobatan. Ia merasa berada di posisi yang tinggi karena membandingkan diri dengan orang lain yang ia anggap posisinya rendah. Pertobatan justru terjadi karena orang melihat dirinya sendiri di hadapan Allah. Dengan merasa berdosa dan rendah di hadapan Allah, orang akan merasa membutuhkan Allah dan bertobat. Sikap inilah yang membuat seseorang dibenarkan dan ditinggikan oleh Allah (ayat 14). Sebaliknya, "jika kita berkata bahwa kita tidak berbuat dosa, maka kita membuat Dia menjadi pendusta dan firmanNya tidak ada di dalam kita" (1Yoh 1:10).

Ada perbedaan antara melakukan sesuatu karena kebutuhan dan kewajiban. Bagi saya, kebutuhan lebih bernuansa positif daripada kewajiban. Perintah kedua dalam Lima Perintah Gereja mewajibkan orang Katolik untuk mengaku dosa sekurangkurangnya satu kali dalam satu tahun. ${ }^{75}$ Meskipun terbilang ringan, umat bisa memiliki gambaran pertobatan sebagai kewajiban belaka jika tidak disertai pemahaman yang memadai. Gambaran pertobatan sebagai kebutuhan akan Allah diharapkan bisa mengoreksi gambaran pertobatan sebagai kewajiban tersebut.

\section{Pertobatan Sebagai Kesempatan dari Allah}

Panggilan untuk bertobat adalah inisiatif Allah. Sepanjang sejarah keselamatan, Allah tak henti-hentinya mewartakan pertobatan. Puncaknya adalah kehadiran Yesus di dunia. Ajakan Yesus untuk bertobat berarti ajakan untuk percaya kepada-Nya. ${ }^{76}$ Warta pertobatan ini tidak berhenti saat Yesus hadir di dunia. Sebelum naik ke surga, Yesus berkata kepada para murid bahwa dalam nama-Nya warta pertobatan harus disampaikan kepada segala bangsa (Luk 24:47).

Yesus tidak sendirian dalam menjalankan misinya untuk mewartakan pertobatan. Ia melibatkan para murid. Salah satu misi para murid yang diutus Yesus berdua-dua adalah mewartakan pertobatan (Mrk 6:12). Setelah Yesus naik ke surga, warta perto- 
batan diteruskan oleh para rasul. Pada hari Pentakosta, Petrus meminta orang-orang yang mendengarkan khotbahnya untuk bertobat (Kis 2:38). Ia pun menyerukan hal yang sama kepada orang-orang di Serambi Salomo setelah peristiwa penyembuhan orang lumpuh di Bait Allah (Kis 3:19). Paulus juga turut serta dalam mewartakan pertobatan. Ia memberitakan pertobatan kepada orang-orang Yahudi, Yunani, dan juga bangsa-bangsa (Kis 20:21, 26:20). ${ }^{77}$

Allah tak henti-hentinya memberi kesempatan kepada manusia untuk bertobat. Kesempatan ini diwartakan terus-menerus melalui para nabi, memuncak dalam diri Yesus, lalu dilanjutkan oleh para rasul, dan Gereja hingga saat ini. Kesempatan ini butuh ditanggapi. Orang yang diwartakan memiliki pilihan untuk menerima atau menolak kesempatan untuk bertobat tersebut. Gambaran ini mirip dengan gambaran pertobatan sebagai kebutuhan akan Allah. Bedanya, gambaran ini dilihat dari perspektif Allah yang memberi kesempatan, sementara kebutuhan akan Allah dilihat dari perspektif manusia yang membutuhkan Allah. Keduanya sama-sama tidak melihat pertobatan sebagai suatu kewajiban, melainkan suatu kebutuhan yang bisa dipenuhi kapan saja karena Allah senantiasa memberikan kesempatan kepada manusia.

\section{Gambaran-gambaran Pertobatan dalam Dokumen Gereja}

Konsili Vatikan kedua berpengaruh besar bagi Gereja kontemporer. Dokumendokumen yang dihasilkan sejak konsili tersebut memberi warna pada gambaran pertobatan. Beberapa gambaran pertobatan dalam dokumen-dokumen Gereja tak lepas dari gambaran pertobatan dalam Kitab Suci, karena Kitab Suci tetap menjadi dasar penulisan dokumen-dokumen tersebut.

\section{Pertobatan Sebagai Pemumian Diri}

Sejak abad pertengahan hingga abad ke20, ekklesiologi Katolik Roma lebih menekankan aspek yang kelihatan. Bellarminus mendefinisikan Gereja sebagai masyarakat yang dibentuk oleh pengakuan iman yang sama, kebersamaan di dalam sakramensakramen, dan ketaatan kepada pimpinan yang sah. $^{78}$ Terutama untuk melawan gerakan Reformasi, Gereja Katolik memandang diri secara eksklusif sebagai societas perfecta (masyarakat sempurna). ${ }^{79}$ Konsili Vatikan II membawa perubahan besar di dalam Gereja. Gereja societas perfecta berubah menjadi Gereja sakramen yang lebih menekankan aspek misteri, persamaan, pelayanan, keterbukaan, dan kesucian. ${ }^{80}$ Ini bukanlah bentuk inkonsistensi Gereja, melainkan kesetiaan kepada Kristus. Gereja dipanggil oleh Kristus untuk memurnikan diri dengan terus melakukan perubahan. Sebagai lembaga manusiawi dan duniawi, Gereja membutuhkan pembaruan. ${ }^{81}$

Pembaruan dalam Konsili Vatikan II membuktikan bahwa Gereja tidak lagi melihat dirinya sebagai masyarakat sempurna, melainkan komunitas yang terusmenerus dipanggil untuk memurnikan dan membarui diri. ${ }^{82}$ Gereja bukanlah Kristus yang suci dan tanpa kesalahan sehingga tidak butuh pertobatan. Walaupun Gereja dipanggil menjadi kudus, warganya jatuh ke dalam dosa. ${ }^{83}$ Gereja itu suci, tapi juga bisa melakukan kesalahan sehingga harus selalu dibersihkan dengan pertobatan dan pembaruan. ${ }^{84}$ Karena itu, Gereja memanggil semua orang beriman untuk bertobat dan terus menerus memperbarui diri. Dalam usaha pemurnian diri yang tiada henti, Gereja membutuhkan Roh Kudus dan Bunda Maria untuk mengantar dirinya kepada persatuan yang sempurna dengan Kristus. ${ }^{85}$

Pemurnian diri bisa dianalogikan dengan membersihkan diri. Mandi, menyapu, mengepel, mencuci, adalah aktivitas membersihkan. Hasilnya tentu saja keadaan bersih, entah itu badan, pakaian, alat-alat makan, lantai, dll. Orang tidak pernah bosan melakukan aktivitas membersihkan karena sadar bahwa dirinya tidak akan pernah lepas dari hal-hal kotor dan perlu selalu dibersihkan. Terlepas dari suka atau tidak suka, kegiatan membersihkan sesuatu selalu melekat dalam hidup. Dengan gambaran ini, pertobatan diharapkan juga bisa menjadi aktivitas yang selalu ada dalam hidup. 


\section{Pertobatan sebagai Pendamaian}

Pada mulanya Allah menjadikan segalanya dengan sungguh amat baik (Kej 1:31). Manusia hidup dalam relasi harmonis dengan Allah, sesama, dan alam ciptaan. Karena manusia jatuh ke dalam dosa, relasi ini rusak. Manusia menyembunyikan diri dari Tuhan (Kej 3:8). Ketika ditanya oleh Tuhan, manusia menyalahkan sesamanya (Kej 3:12). Manusia yang mulanya bisa dengan mudah makan buah dalam taman Firdaus (Kej 2:16-17) kini harus bekerja keras mengolah tanah (Kej 3:17). Manusia perlu didamaikan kembali dengan Allah, sesama, dan alam ciptaan melalui pertobatan. ${ }^{86}$

\section{Pendamaian dengan Allah}

Sejak awal sejarah, manusia memiliki kecenderungan memberontak melawan Allah dan ingin mencapai tujuan di luar Allah. ${ }^{87}$ Meski manusia jatuh ke dalam dosa, Allah selalu menawarkan pendamaian. ${ }^{88}$ Allah tidak menghendaki manusia binasa karena dosa. Karena itu Allah mengutus Putra-Nya, supaya setiap orang yang percaya kepada-Nya tidak binasa, melainkan beroleh hidup yang kekal (Yoh 3:16). Melalui wafat dan kebangkitan Kristus, manusia diperdamaikan kembali dengan Allah. Pendamaian ini pertama-tama adalah inisiatif Allah. Manusia diajak untuk menanggapi tawaran pendamaian Allah melalui Kristus itu dengan iman dan pertobatan. ${ }^{89}$

\section{Pendamaian dengan sesama}

Salah satu gambaran Gereja dalam dokumen Konsili Vatikan II adalah Tubuh Mistik Kristus. ${ }^{90}$ Gambaran ini berasal dari Paulus yang menganalogikan Gereja sebagai satu tubuh yang memiliki banyak anggota (1Kor 12:12-31). Gereja terdiri atas banyak anggota yang telah disatukan dalam satu Roh melalui pembaptisan (ayat 13). Setiap anggota Gereja merupakan anggota dari tubuh mistik Kristus. Setiap anggota memiliki kesatuan dengan Kristus, sekaligus menjadi anggota terhadap yang lain ( $\mathrm{Rm}$ 12:5). Jika satu anggota menderita, semua anggota turut menderita (1Kor 12:26). Jika ada satu warga Gereja berdosa, seluruh Gereja menjadi sakit. Pertobatan mendamai- kan anggota Gereja yang berdosa dengan seluruh Gereja.

\section{Pendamaian dengan alam ciptaan}

Dalam karya penciptaan, manusia diajak Allah untuk berpartisipasi dengan cara menguasai bumi (Kej 1:28). Panggilan ini menciptakan relasi antara manusia dan alam ciptaan. Harmoni ini dirusak karena dosa manusia yang melawan rencana Pencipta. Rusaknya relasi manusia dengan Pencipta berpengaruh terhadap tatanan ciptaan lainnya. Selama manusia tak berdamai dengan Allah, bumi juga tak dapat hidup dalam damai (bdk. Hos 4:1-3). Allah tidak hanya ingin mendamaikan manusia dengan Diri-Nya, tapi juga mendamaikan segalanya, di bumi dan di surga, melalui Kristus (Kol 1:19-20). Pertobatan yang dilakukan manusia sebagai tanggapan atas tawaran pendamaian dari Allah tidak hanya berdampak pada relasi dengan Allah dan sesama, tapi juga dengan alam ciptaan. Dosa manusia, terutama keserakahan, telah membuat alam tercemar, tereksploitasi habis-habisan. Pertobatan semestinya juga berdampak pada pembangunan kembali alam lingkungan. ${ }^{91}$

Pertobatan digambarkan sebagai pendamaian kembali manusia dengan Allah, sesama, dan lingkungan. Tawaran pendamaian datang dari Allah, dan manusia menanggapinya dengan bertobat. Secara sakramental, pendamaian ini diperoleh melalui Sakramen Rekonsiliasi. Mereka yang menerima Sakramen Rekonsiliasi memperoleh pengampunan dari belas kasihan Allah, dan juga didamaikan oleh Gereja, yang telah mereka lukai dengan berdosa..$^{92}$

Proses pendamaian tak ubahnya seperti proses memperbaiki sesuatu yang rusak. Harapannya adalah sesuatu yang rusak itu bisa kembali seperti semula, atau bahkan lebih baik dari sebelumnya. Tentu ada kegembiraan ketika yang rusak itu bisa pulih kembali. Demikian pula tentu ada kegembiraan ketika relasi manusia dengan Allah, sesama, dan alam ciptaan yang rusak karena dosa bisa dipulihkan kembali. 


\section{Pertobatan Sebagai Sakramen Penyembuhan}

Pengampunan dosa sering dikaitkan dengan kesembuhan. Yesus berkata kepada orang lumpuh yang dibawa kepada-Nya melalui atap, "Dosamu sudah diampuni" (Luk 5:18-20). Dalam suratnya, Rasul Petrus menyatakan bahwa Kristus menebus manusia dari dosa dan menyembuhkannya berkat bilur-bilur-Nya (1Ptr 2:24). Rasul Yakobus mengajak jemaat mengaku dosa agar sembuh (Yak 5:16). Dosa menimbulkan luka rohani. Pendosa tidak hanya menyakiti Allah dan sesama, tapi juga dirinya sendiri. Pendosa digambarkan sebagai orang sakit. Layaknya orang sakit yang perlu disembuhkan, pendosa perlu mendapat pengampunan. ${ }^{93}$

Kuasa mengampuni dosa hanya dimiliki Allah. Dalam karya-Nya di dunia, Yesus menegaskan bahwa Ia memiliki kuasa untuk mengampuni dosa (Mat 9:6; Mrk 2:10; Luk 5:24). Kuasa itu diterima Yesus dari Bapa (Mat 28:18). Selanjutnya, kuasa untuk mengampuni tersebut dilimpahkan-Nya kepada para rasul (Mat 16:19; Mat 18:18; Yoh 20:22-23). Inilah yang menjadi dasar praktik pengampunan melalui Sakramen Rekonsiliasi. Kuasa Gereja untuk mengampuni dosa berasal dari Yesus Kristus, dan dilaksanakan secara konkret oleh pelayan Gereja, yaitu imam. $^{94}$ Dalam Sakramen Rekonsiliasi, Allah menganugerahkan Roh Kudus sebagai pengampunan dosa dan kekuatan untuk pembaruan hidup. ${ }^{95}$

Sakramen Rekonsiliasi, yang di dalamnya terdapat pengakuan pribadi dan utuh serta absolusi, merupakan cara biasa satu-satunya bagi orang beriman yang sadar akan dosa beratnya diperdamaikan kembali dengan Allah dan Gereja. ${ }^{96}$ Ajaran ini kembali ditegaskan oleh Paus Yohanes Paulus II dalam dokumen Reconciliatio et Paenitentia yang diterbitkan pada tahun 1984. ${ }^{97}$ Sakramen Rekonsiliasi disebut sakramen penyembuhan karena menyembuhkan penyakit manusia dari sisi rohani maupun psikis. Penyembuhan di sini dikaitkan terutama dengan kehidupan iman, bukan semata-mata penyembuhan secara medis. ${ }^{98}$
Kesembuhan merupakan harapan terbesar bagi orang yang sakit. Kesembuhan juga menjadi salah satu alasan orang mengucapkan syukur. Kesembuhan yang membuat orang bergembira bisa diperlawankan dengan penyakit yang membuat orang menderita. Jika dosa digambarkan sebagai penyakit yang membawa penderitaan, maka pertobatan bisa digambarkan sebagai kesembuhan yang membawa kegembiraan.

\section{Pertobatan Sebagai Tanggapan Sukarela Atas Panggilan Allah}

Sepanjang sejarah keselamatan, Allah tidak pernah meninggalkan manusia meskipun manusia jatuh ke dalam dosa. Allah terus-menerus menawarkan keselamatan, hingga mengutus Yesus Kristus untuk menebus manusia dari dosa. ${ }^{99}$ Allah memanggil semua orang untuk menjalin hubungan pribadi dengan-Nya dalam Kristus. Panggilan ini tidak hanya ditujukan secara eksklusif kepada Gereja, tapi juga kepada segala bangsa. Tujuannya adalah agar berkat Roh Kudus mereka dapat membuka hati, menjadi beriman, dan berpegang teguh kepada Kristus. ${ }^{100}$ Semua orang membutuhkan Yesus sebagai juru selamat. Karena itu, ajakan untuk bertobat terbuka bagi semua orang. ${ }^{101}$

Setiap orang memiliki pilihan untuk menerima atau menolak warta pertobatan. ${ }^{102}$ Allah tidak memaksa, melainkan menuntun orang kepada pertobatan ( $\mathrm{Rm}$ 2:4). Pertobatan harus dilakukan dengan sukarela. ${ }^{103}$ Pertobatan adalah buah dari kesaksian hidup umat beriman sebagai garam dan terang dunia, yaitu penghayatan hidup Kristiani yang mendalam, pengabdian kepada Allah, dan cinta kasih terhadap sesama. Tidak boleh ada paksaan atau siasat yang tidak pada tempatnya agar orang lain memeluk iman. ${ }^{104}$ Gereja tidak memaksa umat beragama dan kepercayaan lain, bahkan yang tidak beragama, untuk dibaptis. Sebaliknya, Gereja diajak untuk menghormati dan berdialog dengan mereka. ${ }^{105}$

Bertobat bukanlah suatu paksaan, melainkan tanggapan berdasarkan pilihan dan kehendak bebas manusia. Kebebasan adalah kodrat manusia yang membedakannya dengan ciptaan lainnya. ${ }^{106}$ Manusia pertama 
jatuh ke dalam dosa karena memilih melanggar larangan Allah. Sebaliknya, Yesus ditinggikan karena memilih taat kepada Bapa melalui sengsara dan wafat-Nya di salib. Kebebasan tidak dimaknai sebagai bebas untuk berdosa (Gal 5:13; 1Ptr 2:16), tetapi bebas dari dosa dan maut berkat Roh yang memberi hidup (Rm 8:2). Di mana ada Roh Allah, di situ ada kemerdekaan (2Kor 3:17). Pertobatan yang didasari kebebasan akan membawa orang kepada pembebasan. Inilah kebebasan yang sejati, yaitu membiarkan diri dibimbing oleh Roh Kudus ke arah mana pun yang Ia mau. ${ }^{107}$

Kegembiraan diperoleh karena seseorang melakukan sesuatu secara bebas, bukan terpaksa. Pertobatan terasa menggembirakan karena dilakukan secara bebas, bukan karena paksaan orang lain, aturan Gereja, takut ditegur oleh pastor, takut dihukum, dsb. Jika hal-hal tersebut menjadi faktor utama yang menentukan apakah seseorang mau bertobat atau tidak, maka pertobatan tidak lagi disebut bebas. ${ }^{108}$

\section{MENUJU GAMBARAN PERTOBATAN YANG MENGGEMBIRAKAN}

Sejak Perjanjian Lama hingga Gereja masa ini, gambaran pertobatan terus mengalami dinamika. Gambaran pertobatan yang dinamis ini dipengaruhi oleh pola pikir masyarakat, doktrin iman, teologi, dan sebagainya. Sebagai contoh, ketika Allah digambarkan sebagai hakim, pertobatan

\section{CATATAN AKHIR}

1 Menurut Injil Markus, seruan pertama Yesus di depan umum adalah "Bertobatlah dan percayalah kepada Injil” (Mrk 1:15).

2 Contohnya adalah jawaban Petrus kepada orangorang di Yerusalem pada hari Pentakosta, "Bertobatlah dan hendaklah kamu masing-masing memberi dirimu dibaptis..." (Kis 2:37-38).

3 Lih. Kitab Hukum Kanonik (KHK) Kanon 960.

4 Lih. Albertus Sujoko, Praktek Sakramen Pertobatan dalam Gereja Katolik: Tinjauan Historis, Dogmatis, dan Pastoral (Yogyakarta: Kanisius, 2008). 19.

5 Bdk. Sujoko, Praktek Sakramen Pertobatan. 25.

6 Lih. I. Bambang Sugiharto, Postmodernisme: Tantangan bagi Filsafat (Yogyakarta: Kanisius, 1996). 166-168.

7 Sebagai contoh, Seruan Apostolik Paus Fransiskus "Amoris Laetitia" dipertanyakan oleh empat kardinal, yaitu Kardinal Carlo Caffarra, Kardinal lebih tampak sebagai persoalan legalitas, yaitu menghindarkan diri dari hukuman. Ketika Allah dihayati sebagai Bapa yang mahakasih dan tidak menghakimi, pertobatan lebih tampak sebagai gambaran yang membahagiakan. Pertobatan tidak lagi diwartakan dengan ancaman, tapi melalui perjumpaan, sapaan, dan penyembuhan. Pertobatan tidak dilakukan karena takut, tapi karena sadar akan jati diri yang membutuhkan Allah.

Kegembiraan menjadi unsur yang penting dalam pewartaan Injil. ${ }^{109}$ Salah satu tugas Gereja adalah mewartakan Kabar Baik, termasuk pertobatan. Tidak hanya sebagai pewarta, Gereja juga diajak untuk menjadi pelaku tobat. Dalam mewartakan dan mengusahakan pertobatan, sudah selayaknya Gereja menampilkan kegembiraan ini. Ajakan pertobatan semestinya membawa sukacita, sebagaimana Injil terus-menerus mengundang manusia untuk bersukacita. ${ }^{110}$ Pertobatan akan membawa Gereja kepada pembaruan. Dengan demikian, gambaran pertobatan yang menggembirakan bisa memotivasi Gereja untuk melakukan pembaruan secara menggembirakan pula.

\section{Aloysius Wahyu Endro Suseno}

Mahasiswa Program Pascasarjana -
Program Magister Ilmu Teologi
Universitas Katolik Parahyangan,
Bandung. Jl. Nias 2, Bandung 40117.
Email:kristohario90@gmail.com

Raymond Burke, Kardinal Walter Brandmüller, dan Kardinal Joachim Meisner pada tanggal 19 September 2016 dalam lima pertanyaan yang disebut Dubia. Lih. http://www.ncregister.com /daily-news/four-cardinals-formally-ask-pope-forclarity-on-amoris-laetitia (diakses pada tanggal 17 Oktober 2017 pukul 15.00)

8 Lih. Al. Purwa Hadiwardoyo, Pertobatan dalam Tradisi Katolik (Yogyakarta: Kanisius, 2007), 32.

$9 \quad$ Bdk. Lih. Avery Dulles, Models of the Church (New York: Doubleday), terj. George Kirchberger (koord.), Model-model Gereja (Yogyakarta: Kanisius, 1990), 21.

10 Bdk. Sujoko, Praktek Sakramen Pertobatan. 22.

11 Lih. Tom Jacobs (ed.), Rahmat bagi Manusia Lemah (Yogyakarta: Kamisius, 1987), 69.

12 Lih. Sujoko, Praktek Sakramen Pertobatan. 146148.

13 Lih. Sujoko, Praktek Sakramen Pertobatan. 133.

14 Bdk. Kees Maas, Teologi Moral Tobat (Ende: Nusa Indah, 1999), 5.

15 Lih. Kees Maas, Teologi Moral Tobat. 
16 Lih. Konstitusi Dogmatis tentang Wahyu Ilahi/Dei Verbum (DV) artikel 11 dan 24.

17 Lih. Konferensi Waligereja Indonesia, Iman Katolik (Yogyakarta: Kanisius, 2007), 215.

18 Lih. Tom Jacobs, Gereja Menurut Vatikan II (Yogyakarta: Kanisius, 1987), 11-12.

19 Bdk. Konstitusi Dogmatis tentang Gereja/Lumen Gentium (LG) artikel 2 dan 9.

20 Lih. E. Martasudjita, Sakramen-sakramen Gereja: Tinjauan Teologis, Liturgis, dan Pastoral (Yogyakarta: Kanisius, 2003), 313.

21 Lih. Walter Brueggemann and Tod Linafelt, An Introduction to the Old Testament: The Canon and Christian Imagination (Louisville: Westminster John Knox Press, 2012), 94.

22 Lih. Sujoko, Praktek Sakramen Pertobatan. 29.

23 Misalnya saat Daud mendengar berita kematian Saul dan Yonatan di medan perang (2 Sam 1:12).

24 Misalnya saat Ester mengajak Mordekhai untuk turut berpuasa ketika ia hendak menghadap raja (Est 4:16).

25 Lih. Donald Guthrie (ed.), The New Bible Commentary (London: Inter-Varsity Press, 1976), terj. Harun Hadiwijono dkk., Tafsiran Alkitab Masa Kini 1 (Jakarta: Yayasan Komunikasi Bina Kasih/OMF, 1982), 657.

26 Abraham menyebut dirinya sebagai abu dan debu ketika bernegosiasi dengan Tuhan perihal Sodom yang akan dimusnahkan (Kej 18:27).

27 Bdk. Donald Guthrie (ed.), The New Bible Commentary (London: Inter-Varsity Press, 1976), terj. Harun Hadiwijono dkk., Tafsiran Alkitab Masa Kini 2 (Jakarta: Yayasan Komunikasi Bina Kasih/OMF, 1985), 605.

28 Pertobatan sebagai tindakan dibedakan antara penyesalan batin yang tidak tampak (metanoein dalam Bahasa Yunani) dan tindakan lahiriah yang tampak (epistrephein dalam Bahasa Yunani). Lih. Kees Maas, Teologi Moral Tobat. 30.

29 Bdk. Martasudjita, Sakramen-sakramen Gereja:, 313.

30 Bdk. Andres Fatubun, Orangnya Itu-itu Saja, di Majalah Komunikasi Keuskupan Bandung edisi 320, Maret 2007, 6-10.

31 Lih. Walter Brueggemann, Deuteronomy (Nashville: Abingdon Press, 2001), 17.

32 Lih. Walter Brueggemann, Deuteronomy, 17

33 Lih. Brueggemann and Linafelt, An Introduction to the Old Testament: 113-114.

34 Lih. Martasudjita, Sakramen-sakramen Gereja:, 313.

35 Bdk. Ul 31:29; 2Sam 12:11; 1Raj 9:9; 2Raj 21:1112; 2Taw 7:22; Neh 13:17-18; Dan 9:13-14.

36 Bdk. Kees Maas, Teologi Moral Tobat. 35.

37 Ejaan yang digunakan Brueggemann adalah"sub". Lih. Brueggemann, Deuteronomy, 266.

38 Lih. Kees Maas, Teologi Moral Tobat. 30

39 Istilah "segenap hati dan segenap jiwa" terdapat dalam beberapa teks, misalnya dalam Ul 30:10; 1Raj 8:48; 2Raj 23:25; 2Taw 6:38.

40 Bdk. Yos 24:19-20, 1Sam 7:3, 1Raj 9:6-7, Yer 4:1, Hos 14:2-9

41 Teks-teks yang menyebutkan istilah "tingkah laku yang jahat" misalnya Neh 9:35; Yes 1:16; Yer 26:3; Yer 36:3; Yeh 3:19; Yun 3:8-10; Za 1:4. Istilah lain yang maknanya serupa dengan itu adalah "jalan yang jahat" (2Raj 17:13; 2Taw 7:14) dan kesalahan (Dan 9:13; Mal 2:6).

42 Bdk. Kees Maas, Teologi Moral Tobat. 32-34.

43 Bdk. Robert W. Crapps, An Introduction to Psychology of Religion (Macon, Georgia: Mercer University Press, 1986), terj. Agus M. Hardjana, Perkembangan Kepribadian dan Keagamaan (Yogyakarta: Kanisius, 1994), 112-117.

44 Bdk. Franz Magnis Suseno, Etika Jawa, Sebuah Analisa Falsafi tentang Kebijaksanaan Hidup Jawa (Jakarta: PT Gramedia Pustaka Utama, 1984), 141 dan 150.

45 Dalam teks aslinya, Pastor Wim MSF menggunakan kata-kata "reaksi satu-satunya yang tepat". Lih. Wim van der Weiden, Mazmur dalam Ibadat Harian (Yogyakarta: Kanisius, 1991), 8586.

46 Bdk. Kees Maas, Teologi Moral Tobat. 88-89.

47 Lih. Kees Maas, Teologi Moral Tobat. 88-89.

48 Lih. Sujoko, Praktek Sakramen Pertobatan. 148.

49 Bdk. John Paul Lederach, The Journey Toward Reconciliation (Scottdale: Herald Press, 1999), 17 22.

50 Bdk. John L. McKenzie, The Old Testament Without Illusion (New York: Image Books, 1980), 177-186.

51 Selain "mencuri" berkat, sebelumnya Yakub pernah mengiming-imingi Esau dengan masakan kacang merah asalkan Esau memberikan hak kesulungannya kepada Yakub (Kej 25:29-34).

52 Bdk. John Paul Lederach, The Journey Toward Reconciliation, 167-171.

53 Bdk. Sujoko, Praktek Sakramen Pertobatan. 2930.

54 Ejaan di Kitab Suci adalah "Kerajaan Sorga". Istilah ini sama artinya dengan "Kerajaan Allah". Lih. David M. Stanley, New Testament Reading Guide, The Gospel of St. Matthew(Collegeville, Minnesota: The Liturgical Press), terj. Lembaga Biblika Indonesia, Tafsir Injil Matius (Yogyakarta: Kanisius, 1981), 44

55 Dalam Kamus Besar Bahasa Indonesia, imperatif berarti bersifat memerintah, mengharuskan atau melarang, sedangkan indikatif berarti bersifat atau mengandung indikasi.

56 Lih. John Fuellenbach, The Kingdom of God: The Central Message of Jesus' Teaching in the Light of the Modern World (Indore: Satprakashan Sanchar Kendra, 1994), terj. Eduard Jebarus, Kerajaan Allah: Pesan Inti Ajaran Yesus Bagi Dunia Modern (Ende: Nusa Indah, 2006), 110-112.

57 Bdk. Donald Guthrie (ed.), The New Bible Commentary (London: Inter-Varsity Press, 1976), terj. Harun Hadiwijono dkk.,Tafsiran Alkitab Masa Kini 3 (Jakarta: Yayasan Komunikasi Bina Kasih/OMF, 1983), 135.

58 Lih. Gerard S. Sloyan, New Testament Reading Guide, The Gospel of St. Mark (Collegeville, Minnesota: The Liturgical Press), terj. Lembaga Biblika Indonesia, Tafsir Injil Markus (Yogyakarta: Kanisius, 1982), 25.

59 Lih. John Fuellenbach, The Kingdom of God:, 240

60 Bdk. C. Groenen, Peristiwa Yesus (Yogyakarta: Kanisius, 1979), 110-113.

61 Bdk. Guthrie (ed.), terj. Harun Hadiwijono dkk., Tafsiran Alkitab Masa Kini 3, loc.cit. 
62 Bdk. James McPolin, John: New Testament Message 6 (Wilmington: Michael Glazier Inc, 1979), 121-123.

63 Bdk. Groenen, Peristiwa Yesus, 113.

64 Bdk. St. Darmawijaya, Jiwa dan Semangat Perjanjian Baru (Yogyakarta: Kanisius, 1992), 109.

65 Lih. I. Suharyo, Menjadi Manusia Dewasa: Belajar dari Pengalaman St. Paulus, (Yogyakarta: Kanisius, 2008), 18-32.

66 Lih. I. Suharyo, Menjadi Manusia Dewasa:, 38-59.

67 Lih. I. Suharyo, Menjadi Manusia Dewasa:, 60-66.

68 Bdk. Paradoks dan Seruan (Yogyakarta: Kanisius, 2004), 134.

69 Bdk. Guthrie (ed.), terj. Harun Hadiwijono dkk., Tafsiran Alkitab Masa Kini 3, op.cit., 241.

70 Bdk. Raymond E. Brown, New Testament Reading Guide, The Gospel of St. John; The Johannine Epistles (Collegeville, Minnesota: The Liturgical Press), terj. Lembaga Biblika Indonesia, Tafsir Injil dan Surat-surat Yohanes, (Yogyakarta: Kanisius, 1981), 145-146.

71 Bdk. St. Darmawijaya, Jiwa dan Semangat Perjanjian Baru, 80.

72 Bdk. Adelbert Snijders, Antropologi Filsafat Manusia, 13-14.

73 Lih. I. Bambang Sugiharto \& Agus Rachmat W., Wajah Baru Etika \& Agama (Yogyakarta: Kanisius, 2000), 158 dan 162

74 Lih. Carroll Stuhlmueller, New Testament Reading Guide, The Gospel of St. Luke (Collegeville, Minnesota: The Liturgical Press), terj. Lembaga Biblika Indonesia, Tafsir Injil Lukas (Yogyakarta: Kanisius, 1981), 186-187.

75 Lih. Katekismus Gereja Katolik (KGK) 2042, bdk. KHK Kan. 989.

76 Lih. Al. Purwa Hadiwardoyo, Pertobatan dalam Tradisi Katolik, 17.

77 Lih. Al. Purwa Hadiwardoyo, Pertobatan dalam Tradisi Katolik, 19-20.

78 Lih. Avery Dulles, Models of the Church, 16-17.

79 Lih. ibid., 28.

80 Lih. Jacobs, Gereja Menurut Vatikan II, op.cit., 69.

81 Bdk. Dekret tentang Ekumenisme/Unitatis Redintegratio (UR) artikel 6.

82 Lih. LG 15 dan 43.

83 Pernyataan ini terdapat dalam Konstitusi Apostolik tentang Pertobatan/Paenitemini yang diterbitkan oleh Paus Paulus VI pada tahun 1966. Lih. Al. Purwa Hadiwardoyo, Pertobatan dalam Tradisi Katolik, 39

84 Lih. $L G 8$

85 Lih. $L G$ 4, 15, dan 43

86 Bdk. Kees Maas, Teologi Moral Tobat. 21.

87 Lih. Konstitusi Pastoral tentang Gereja di Dunia Dewasa Ini/Gaudium et Spes (GS) artikel 13.

88 Lih. LG 2-3.

89 Lih. Martasudjita, Sakramen-sakramen Gereja:, 324.

$90 \quad$ Lih. $L G 7$.

91 Lih. Paus Fransiskus, Laudato Si/LS (2015), terj. Martin Harun, Ensiklik Terpujilah Engkau
(2016), artikel 216-221 tentang Pertobatan Ekologis.

92 Lih. LG 11 dan Dekret tentang Pelayanan dan Kehidupan Para Imam/Presbyterorum Ordinis (PO) artikel 5.

93 Introduksi Tata Ibadat Tobat/Misericordiam Suam yang diterbitkan tahun 1974 oleh Kongregasi Suci Urusan Ibadat menyebut istilah "penyembuhan luka dosa”. Lih. Michael Marsch, Healing Through the Sacraments (Collegeville, Minnesota: The Liturgical Press), terj. Sikun Pribadi, Penyembuhan melalui Sakramen (Yogyakarta: Kanisius, 2006), 83-84.

94 Bdk. Martasudjita, Sakramen-sakramen Gereja:, 314-315.

95 Lih. Martasudjita, Sakramen-sakramen Gereja: 326.

96 Lih. KHK Kan. 960

97 Lih. Al. Purwa Hadiwardoyo, Pertobatan dalam Tradisi Katolik, 48.

98 Lih. Martasudjita, Sakramen-sakramen Gereja: 311.

99 Lih. LG 2-3.

100 Lih. Dekret tentang Kegiatan Misioner Gereja/Ad Gentes (AG) artikel 13.

101 Lih. AG 8.

102 Bdk. GS 82.

103 Lih. AG 36.

104 Lih. $A G 13$

105 Lih. Surat Anjuran Sukacita Injil dari Paus Fransiskus/Evangelii Gaudium (EG) artikel 244258.

106 Lih. Nico Syukur, Teologi Sistematika 2: Ekonomi Keselamatan (Yogyakarta: Kanisius, 2004), 102105.

107 Lih. EG 280

108 Bdk. Adelbert Snijders, Antropologi Filsafat Manusia, 123

109 Lih. EG 1.

110 Lih. EG 5.

\section{DAFTAR PUSTAKA}

Brueggemann, Walter and Tod Linafelt. An Introduction to the Old Testament: The Canon and Christian Imagination. Louisville: Westminster John Knox Press, 2012.

Brueggemann, Walter. Deuteronomy. Nashville: Abingdon Press, 2001.

Crapps, Robert W. An Introduction to Psychology of Religion. Macon, Georgia: Mercer University Press, 1986. Terj. Agus M. Hardjana. Perkembangan Kepribadian dan Keagamaan. Yogyakarta: Kanisius, 1994. 
Darmawijaya, St. Jiwa dan Semangat Perjanjian Baru. Yogyakarta: Kanisius, 1992.

Dulles, Avery. Models of the Church. New York: Doubleday, 1987. Terj. George Kirchberger (koord.). Model-model Gereja. Yogyakarta: Kanisius, 1990.

Fuellenbach, John. The Kingdom of God: The Central Message of Jesus' Teaching in the Light of the Modern World. Indore: Satprakashan Sanchar Kendra, 1994. Terj. Eduard Jebarus. Kerajaan Allah: Pesan Inti Ajaran Yesus Bagi Dunia Modern. Ende: Nusa Indah, 2006.

Groenen, C. Peristiwa Yesus. Yogyakarta: Kanisius, 1979.

Hadiwardoyo, Al. Purwa. Pertobatan dalam Tradisi Katolik. Yogyakarta: Kanisius, 2007.

Jacobs, Tom. Gereja Menurut Vatikan II. Yogyakarta: Kanisius, 1987.

. Rahmat bagi Manusia Lemah. Yogyakarta: Kanisius, 1987.

Lederach, John Paul. The Journey Toward Reconciliation. Scottdale: Herald Press, 1999.

Maas, Kees. Teologi Moral Tobat. Ende: Nusa Indah, 1999.

Marsch, Michael. Healing Through the Sacraments. Collegeville, Minnesota: The Liturgical Press. Terj. Sikun Pribadi. Penyembuhan melalui Sakramen. Yogyakarta: Kanisius, 2006.

Martasudjita, E. Sakramen-sakramen Gereja: Tinjauan Teologis, Liturgis, dan Pastoral. Yogyakarta: Kanisius, 2003.

McKenzie, John L. The Old Testament Without Illusion. New York: Image Books, 1980.

McPolin, James. John: New Testament Message 6. Wilmington: Michael Glazier, Inc., 1979.
Snijders, Adelbert. Antropologi Filsafat Manusia, Paradoks dan Seruan. Yogyakarta: Kanisius, 2004.

Sugiharto, I. Bambang. Postmodernisme: Tantangan bagi Filsafat. Yogyakarta: Kanisius, 1996.

Sugiharto, I. Bambang \& Agus Rachmat W. Wajah Baru Etika \& Agama. Yogyakarta: Kanisius, 2000.

Suharyo, I. Menjadi Manusia Dewasa: Belajar dari Pengalaman St. Paulus. Yogyakarta: Kanisius, 2008.

Sujoko, Albertus. Praktek Sakramen Pertobatan dalam Gereja Katolik: Tinjauan Historis, Dogmatis, dan Pastoral. Yogyakarta: Kanisius, 2008.

Suseno, Franz Magnis. Etika Jawa, Sebuah Analisa Falsafi tentang Kebijaksanaan Hidup Jawa. Jakarta: PT Gramedia Pustaka Utama, 1984.

Syukur, Nico. Teologi Sistematika 2: Ekonomi Keselamatan. Yogyakarta: Kanisius, 2004.

van der Weiden, Wim. Mazmur dalam Ibadat Harian. Yogyakarta: Kanisius, 1991.

\section{Referensi}

Brown, Raymond E. New Testament Reading Guide, The Gospel of St. John; The Johannine Epistles. Collegeville, Minnesota: The Liturgical Press. Terj. Lembaga Biblika Indonesia. Tafsir Injil dan Surat-surat Yohanes. Yogyakarta: Kanisius, 1981.

Departemen Pendidikan dan Kebudayaan RI. Kamus Besar Bahasa Indonesia Edisi Kedua. Jakarta: Balai Pustaka, 1996.

Guthrie, Donald (ed.). The New Bible Commentary. London: Inter-Varsity Press, 1976, Terj. Harun Hadiwijono dkk. Tafsiran Alkitab Masa Kini 1. Jakarta: Yayasan Komunikasi Bina Kasih/OMF, 1982. 
. The New Bible Commentary. London: Inter-Varsity Press, 1976, Terj. Harun Hadiwijono dkk. Tafsiran Alkitab Masa Kini 2. Jakarta: Yayasan Komunikasi Bina Kasih/OMF, 1985.

. The New Bible Commentary. London: Inter-Varsity Press, 1976, Terj. Harun Hadiwijono dkk. Tafsiran Alkitab Masa Kini 3. Jakarta: Yayasan Komunikasi Bina Kasih/OMF, 1983.

Konferensi Waligereja Indonesia. Iman Katolik. Yogyakarta: Kanisius, 2007.

Lembaga Alkitab Indonesia. Alkitab. Jakarta: Lembaga Alkitab Indonesia, 2010.

Sloyan, Gerard S. New Testament Reading Guide, The Gospel of St. Mark. Collegeville, Minnesota: The Liturgical Press. Terj. Lembaga Biblika Indonesia. Tafsir Injil Markus. Yogyakarta: Kanisius, 1982.

Stanley, David M. New Testament Reading Guide, The Gospel of St. Matthew. Collegeville, Minnesota: The Liturgical Press. Terj. Lembaga Biblika Indonesia. Tafsir Injil Matius. Yogyakarta: Kanisius, 1981.

Stuhlmueller, Carroll. New Testament Reading Guide, The Gospel of St. Luke. Collegeville, Minnesota: The Liturgical Press. Terj. Lembaga Biblika Indonesia. Tafsir Injil Lukas. Yogyakarta: Kanisius, 1981.

\section{Dokumen Gereja}

Fransiskus, Paus. Evangelii Gaudium, 2013. Terj. Bernardinus Yustisianto. Surat Anjuran Sukacita Injil, 2014.

Laudato Si, 2015. Terj. Martin Harun. Ensiklik Terpujilah Engkau, 2016.

Konferensi Waligereja Regio Nusa Tenggara. Katekismus Gereja Katolik. Ende: Nusa Indah, 1995.

Konsili Vatikan II. Dekret tentang Ekumenisme (Unitatis Redintegratio), 1964.

. Dekret tentang Kegiatan Misioner Gereja (Ad Gentes), 1965.

Dekret tentang Pelayanan dan Kehidupan Para Imam (Presbyterorum Ordinis), 1965.

. Konstitusi Dogmatis tentang Gereja (Lumen Gentium), 1964.

. Konstitusi Dogmatis tentang Wahyu Ilahi (Dei Verbum), 1965.

Konstitusi Pastoral tentang Gereja di Dunia Dewasa Ini (Gaudium et Spes), 1965.

Takhta Apostolik. Kitab Hukum Kanonik (Edisi Resmi Bahasa Indonesia). Jakarta: Konferensi Waligereja Indonesia, 2016. 